\section{Last man standing}

\section{Whatever happened to 'boy meets girl'?}

\section{Xaviera Young}

She lay with her head in his lap as the first rays of a rather apocalyptic sunset touched the ocean. Long light slanted over them. He twisted her hair between his fingers and looked rather serious. "Marry me," he said. Gulls cried as they flew over the warm water and the scrubby grass of a brown field. She watched the horizon, shielding her eyes. "Not if you were the last man on Earth," she said, smiling, turning back. She laughed. He laughed. Abruptly they both stopped laughing.

Things had once been good for them both. They had once rolled together in the green grass and giggled madly. She would tease him, he would stare her down with slate-grey eyes that reminded her of storms battering against stony cliffs, and she would give in and give up and all would be bliss. Still, even then she didn't think of marriage. He wasn't ... special enough ... somehow. How things change. In the blink of an eye, she had come to realize how pathetically unspecial she was, really, whereas he had transformed into someone tragically unique. What kind of joke was that?

"I have the virus, you know," he said. She kept her eyes on the Sun. The gulls swooped. She sighed. "I know. You have white spots on the back of your hands. You haven't hidden it verywell.

"It's so unfair," she said suddenly, bolting upright, his arm still around her. "Why couldn't you have stayed well just a bit longer? A year. Two. They would have worked out a cure. Don't smirk, they would have. If you'd stuck around to give them a reason to bother. At least now they know what it is."

The Y-Virus. Colloquially known as just ' $\mathrm{Y}$ ', or 'why' as the various plague-wracked men shrieked on the televised news reports: always good for the ratings. A virus that only hit men. And hit it did. Efficient, ruthless, selfish, domineering, the Y-virus was; a twist that did not escape those same newsreaders. Jokes were made. Until the scope of it came home. The death toll climbed relentlessly. The virus chewed its way through chromosomes around the globe, bringing mankind to its knees. There were surprisingly few riots, little looting. Conflicts came to an end, high finance geared down a notch. For a while, romances burst into flame as they do in the times before a war: love flickered around the

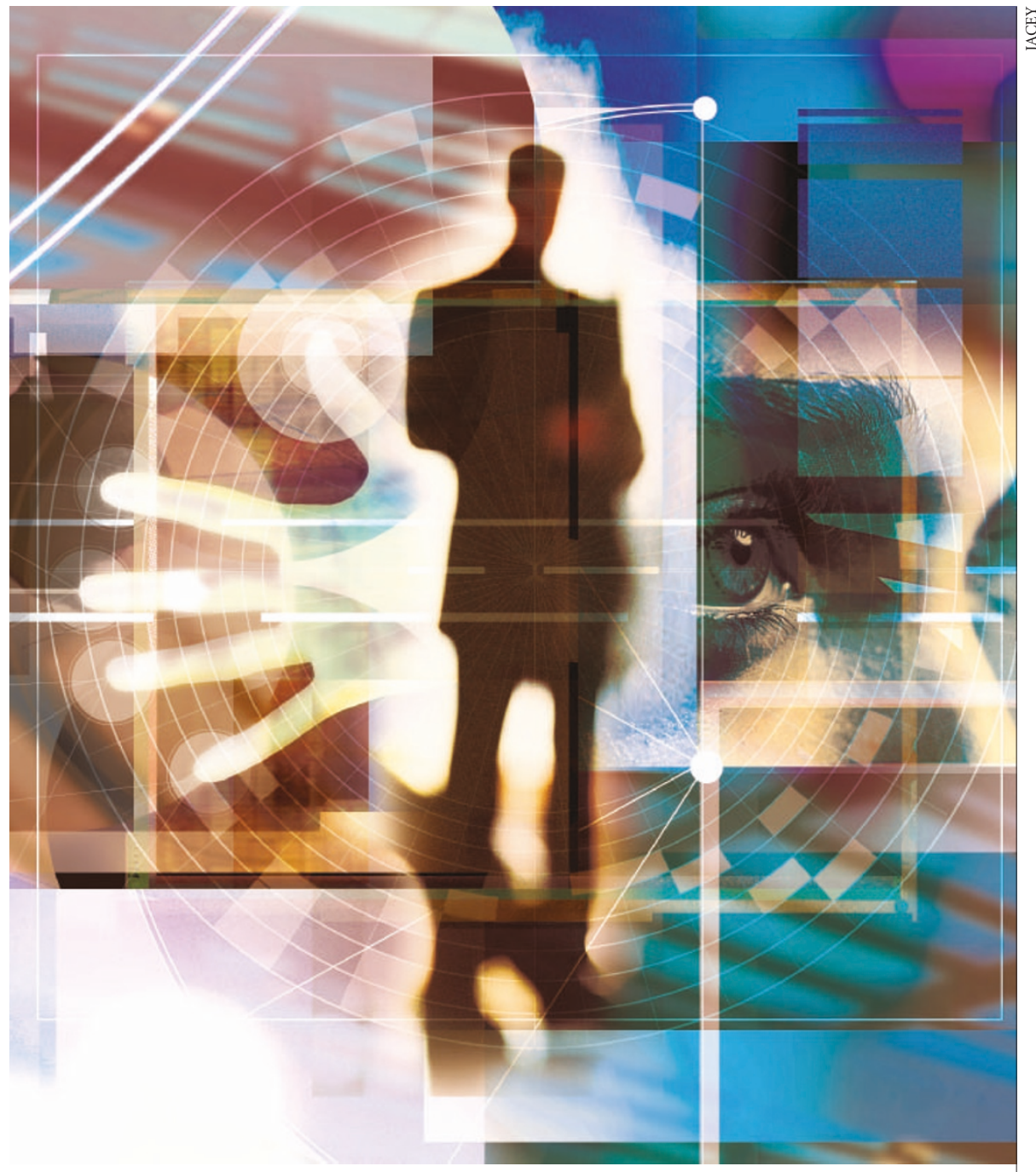

globe as men and women threw themselves into last-minute passions. Many new lives were started in those months, although many — about half, in fact - never made it. It was sexually transmitted, of course. That was the other joke. Not really very funny.

She flopped back in his lap, and he held her as if she were the one in pain. She cried. But she didn't know for whom. For him? Or for the greater loss. A planet with no more moonlight strolls, not really. No more romantic picnics under bowed, green limbs. No more vicious fights fuelled by lust."What will happen to us? To all of us?" she sobbed, limp in his arms. "There's only one thing in life, really, one story. Boy meets girl. Always was. What the hell happens to that?"

"It'll be girl meets girl, I suppose. Just as good, maybe."

Men, she despaired. All the same.

Life will go on, of course, she knew. Women slipped into the slots of heads-ofstate without too much fuss. And there were clones now, the eldest well into their crucial childbearing years and proving the safety or at least the viability - of the technology. It would be man's legacy, cloning. Well done, she thought bitterly. Maternity wards had now been handed over to stem-cell research.
Babies were and will be born, many of them much the same as their mothers. But what kind of life would that be?

Their sighs floated over the field. A lone cow perked its ears and shuffled away. Their pain was palpable. He slipped his hand into hers, and brushed a stray strand of hair from her face. "You could come with me you know."

She spun the ring on her finger and stared at the Sun, blood red on the horizon. Pollution made for such lovely sunsets. The world was getting better, in some ways. With a $50 \%$ cut in population came instability, but also the end of famine. Carbon emissions were plummeting. Not that any of that made any real difference to her, she had to admit. It never did. Tens of thousands died every day in the good old days - without food, choking in cities - and she never noticed or really, to be honest, much cared. She noticed those dying now. She didn't like it.

He opened his palm to reveal a handful of white pills, as the last gasp of a rather apocalyptic sunset slipped over the horizon.

She swallowed. He swallowed. It was the end of the last and only story.

Xaviera Young is a freelance writer based in

Vancouver, Canada. 